\title{
Kaempferitrin from Uncaria guianensis (Rubiaceae) and its Potential as a Chemical Marker for the Species
}

\author{
Ligia M. M. Valente, ${ }^{*, a}$ Carlos H. B. Bizarri, ${ }^{b}$ Sally Liechocki, ${ }^{a}$ Rodolfo S. Barboza, ${ }^{a}$ Djavan da Paixão, ${ }^{a}$ \\ M. Beatriz S. Almeida, ${ }^{b}$ Paulo J. C. Benevides, ${ }^{b}$ Alvicler Magalhães ${ }^{c}$ and Antonio C. Siani $^{b}$ \\ ${ }^{a}$ Instituto de Química, Universidade Federal do Rio de Janeiro, 21941-909 Rio de Janeiro-RJ, Brazil \\ ${ }^{b}$ Instituto de Tecnologia em Fármacos, Fundação Oswaldo Cruz, 21041-250 Rio de Janeiro-RJ, Brazil \\ 'Instituto de Química, Universidade Estadual de Campinas, CP 6154, 13083-970 Campinas-SP, Brazil
}

\begin{abstract}
Uncaria tomentosa (Willd.) DC. e U. guianensis (Aubl.) Gmel., conhecidas como unha-de-gato, são trepadeiras lenhosas nativas das florestas tropicais amazônica e central-americana. As espécies contêm, em diferentes proporções, alcalóides indólicos e oxindólicos, triterpenóides glicosilados, esteróides e proantocianidinas. $U$. tomentosa é quimicamente identificada pelo perfil e conteúdo de alcalóides oxindólicos, ao passo que $U$. guianensis não possui um marcador químico efetivo. Nesse trabalho descreve-se o isolamento de canferol-3,7-O- $(\alpha)$-dirramnosídeo (canferitrina) pela primeira vez em espécies do gênero Uncaria. A triagem para essa substância em folhas, galhos ou cascas das duas espécies por CCD e CLAE-DAD-EM demonstrou a presença de canferitrina apenas nas folhas e galhos de $U$. guianensis, numa proporção cerca de trinta e seis vezes maior nas folhas do que nos galhos. Estes resultados revelaram a seletividade da $U$. guianensis em produzir o flavonóide glicosilado, sugerindo esta substância como um marcador químico potencial para a espécie.
\end{abstract}

Uncaria tomentosa (Willd.) DC. and U. guianensis (Aubl.) Gmel., known as cat's claw, are large woody vines native to the Amazonian and Central American rainforests. The species contain, in different proportions, indole and oxindole alkaloids, triterpenoid glycosides, sterols and proanthocyanidins. $U$. tomentosa can be chemically identified by its oxindole alkaloid profile and content, whereas $U$. guianensis has no satisfactorily established chemical markers. This work describes, for the first time, the isolation of kaempferol-3,7-O- $(\alpha)$-dirhamnoside (kaempferitrin) in Uncaria species. Screening for this compound in leaves, stems or bark of both species through TLC and HPLC-DAD-MS showed the presence of kaempferitrin only in the leaves and stems of $U$. guianensis, at a ratio almost thirty six times greater in the leaves than in the stems. These results reveal the selectivity of $U$. guianensis to produce this bioactive flavonoid glycoside, and suggest this compound as a potential chemical marker for the species.

Keywords: Uncaria guianensis, Uncaria tomentosa, Rubiaceae, kaempferitrin, cat's claw

\section{Introduction}

The genus Uncaria (Rubiaceae) contains 34 species distributed among the tropical areas of Southeast Asia, Africa and Central and South America. ${ }^{1}$ It is represented in Central and South America by two species: $U$. tomentosa and $U$. guianensis. ${ }^{2}$ These species, known as cat's claw, unha-degato (Brazil), uña de gato, garabato etc., are large woody vines that have been used medicinally by indigenous peoples to treat several diseases for at least two thousand years. ${ }^{3,4}$

*e-mail: valente@iq.ufrj.br
From the genus Uncaria there have so far been isolated over 150 compounds with a predominance of alkaloids. Other classes of isolated compounds include terpenoids and terpenoid glycosides, flavonoids (specially flavanols and flavonols) and coumarins. ${ }^{5,6}$ The South American species $U$. tomentosa and $U$. guianensis present some morphological differences ${ }^{2,7}$ and $U$. tomentosa can be further identified by its oxindole alkaloid profile and content. ${ }^{8}$ On the other hand, these alkaloids are present in $U$. guianensis at very low concentration ${ }^{9,10}$ and no satisfactory chemical markers have been established for this species so far. ${ }^{11}$ 
Previous chemical studies of $U$. guianensis revealed indole and oxindole alkaloids (whole plant), ${ }^{9}$ proanthocyanidins (bark), ${ }^{12}$ flavonols (bark) ${ }^{13}$ and triterpenoid glycosides (bark). ${ }^{13,14}$ In vitro and clinical studies using a decoction of $U$. guianensis bark have corroborated its traditional use as an anti-inflammatory and an antioxidant. ${ }^{12,15}$ Bioassay-guided fractionation of the EtOH extract of $U$. guianensis bark using a yeast-based assay for DNA-damaging agents lead to two weakly but selectively active oxindole alkaloids. ${ }^{16}$ The EtOH extract of the leaves of $U$. guianensis showed anti-inflammatory and anti-allergic activities. ${ }^{17}$

The present work describes the isolation of kaempferol3,7-O- $(\alpha)$-dirhamnoside (kaempferitrin) from the leaves of $U$. guianensis and the screening for this compound in the EtOH extracts from the leaves, stems or bark of $U$. guianensis and $U$. tomentosa through TLC and HPLC-DAD-MS techniques.

\section{Experimental}

\section{General experimental procedures}

NMR spectra were recorded on a Bruker DRX-400 (400 MHz for ${ }^{1} \mathrm{H}$ and $100 \mathrm{MHz}$ for ${ }^{13} \mathrm{C}$ ) spectrometer in DMSO- $\mathrm{d}_{6} /$ drops $\mathrm{D}_{2} \mathrm{O}$ with TMS as internal standard. Chemical shifts $(\delta)$ are given in ppm and coupling constants $(J)$ in Hz. The TLC analyses were made using pre-coated silica-gel $60 \mathrm{~F}_{254}$ (Merck), mobile phase EtOAc/HCOOH/ $\mathrm{HOAc} / \mathrm{H}_{2} \mathrm{O}$ 100:11:11:27 and UV irradiation (254 and $326 \mathrm{~nm}$ ) and NP/PEG reagent followed by UV at $365 \mathrm{~nm}$ to visualize the spots. ${ }^{18}$ The HPLC analyses were performed on a Shimadzu HPLC system (Kyoto, Japan) composed of a system controller SCL-10Avp, SIL-10ADvp auto injector, two LC-10ADvp pumps, DGU-12A degasser, SPDM10Avp diode array detector and equipped with a reversephase C18 column (Lichrocart Lichrospher $5 \mu \mathrm{m}, 250 \times$ $4.6 \mathrm{~mm}$ i.d.). Elutions were performed in a gradient elution mode at a $0.8 \mathrm{~mL} \mathrm{~min}^{-1}$ flow: $10 \mathrm{~min} 10 \%$ solvent $\mathrm{B}(\mathrm{MeCN})$ in solvent $\mathrm{A}\left(\mathrm{H}_{2} \mathrm{O}\right.$ with ca. $\left.0.1 \% \mathrm{HCOOH}, \mathrm{pH} 3\right), 10-23 \mathrm{~min}$ $10-40 \%$ solvent B in A and finally 12 min $40 \%$ solvent B in A. An equilibration period of 10 min was used between the runs. The diode-array detector was set at an acquisition range of 200-600 $\mathrm{nm}$ at a spectral acquisition rate of 156 scans $\mathrm{s}^{-1}$ (peak width $0.2 \mathrm{~min}$ ). Flavonol monitoring was performed at $280 \mathrm{~nm}$ and $320 \mathrm{~nm}$. The diode-array detector was coupled to a Micromass ZQ single quadrupole mass spectrometer. The conditions for positive ionization mode in the electrospray probe were: capillary $3.0 \mathrm{kV}$, cone $50 \mathrm{~V}$, extractor $3 \mathrm{~V}$, RF lens $1 \mathrm{~V}$, source temperature $100^{\circ} \mathrm{C}$ and $250^{\circ} \mathrm{C}$ desolvation temperature. Acquisition was obtained in the $\mathrm{m} / \mathrm{z}$ 100-700 range. Retention times, UV spectra and
MS ions (and their relative abundances) in comparison to those of the isolated kaempferitrin were evaluated.

\section{Plant material}

The specimens used in this work were collected in three different locations in the Brazilian Amazon rainforest. U. guianensis was collected in Juruena, Mato Grosso (MT) state (12 $50^{\prime} \mathrm{S}, 58^{\circ} 55^{\prime} \mathrm{W} ; 277 \mathrm{~m}$ elevation) and in Manaus, Amazonas state (AM) ( $3^{\circ} 05^{\prime} \mathrm{S}, 60^{\circ} 00^{\prime} \mathrm{W} ; 55 \mathrm{~m}$ elevation). The specimen from Mato Grosso was identified by the botanist Pierro Delprete (New York Botanic Garden) and a voucher deposited in the Central Herbarium of the Universidade Federal do Mato Grosso, Brazil, under No. 24715. A voucher specimen from the Amazonas state sample was deposited at the Centro de Biotecnologia da Amazônia, in Manaus. U. tomentosa was collected in the valley of the Juruá river, Acre state (AC) ( $7^{\circ} 40^{\prime} \mathrm{S}, 72^{\circ} 38^{\prime} \mathrm{W}$; $192 \mathrm{~m}$ elevation); for voucher data see Miranda et al. ${ }^{19}$

\section{Isolation of kaempferitrin}

Leaves of $U$. guianensis from MT were exhaustly extracted with EtOH as previously described. ${ }^{17}$ The ethanol extract $(2 \mathrm{~g})$ was partitionated between $\mathrm{CH}_{2} \mathrm{Cl}_{2} / \mathrm{H}_{2} \mathrm{O}$ to yield an insoluble yellowish solid $(27 \mathrm{mg}$ ) from the aqueous fraction.

\section{Screening for kaempferitrin in U. tomentosa and $U$. guianensis}

Dried and milled leaves and stems of $U$. guianensis from AM, bark of $U$. guianensis from MT and leaves and bark of $U$. tomentosa from AC (5 g of each sample) were exhaustedly and ultrasonically extracted with EtOH. The solvent was evaporated at low pressure and the dried extracts were partitioned with $n$-hexane and $\mathrm{MeOH} / \mathrm{H}_{2} \mathrm{O}$ 9:1. The EtOH extract ( $5 \mathrm{~g}$ ) previously obtained from the leaves of $U$. guianensis from MT were also partitioned in a similar way. Aliquots of $10 \mu \mathrm{L}$ of the $\mathrm{MeOH}$ solutions ( $c=25 \mathrm{mg} \mathrm{mL}^{-1}$ ) of the $n$-hexane and $\mathrm{MeOH} / \mathrm{H}_{2} \mathrm{O}$ fractions were compared to the isolated kaempferitrin $\left(\mathrm{c}=1 \mathrm{mg} \mathrm{mL}^{-1}\right)$ by TLC. The $\mathrm{MeOH} / \mathrm{H}_{2} \mathrm{O}$ fractions and the isolated kaempferitrin solutions all at $\mathrm{c}=1 \mathrm{mg} \mathrm{mL}^{-1}$ were filtered through $0.45 \mu \mathrm{m}$ nylon membranes and injected $(20 \mu \mathrm{L})$ into the HPLC system. $\mathrm{MeOH} / \mathrm{H}_{2} \mathrm{O}$ fractions of bark of $U$. guianensis and leaves and bark of $U$. tomentosa were further subjected to Sephadex LH-20 cc eluted sequentially with $n$-hexane/ $\mathrm{CH}_{2} \mathrm{Cl}_{2}$ 1:4, $\mathrm{CH}_{2} \mathrm{Cl}_{2}$ /acetone 3:2 and $\mathrm{MeOH}$, in order to concentrate the polyphenolic compounds and thus better visualize the presence (or not) of kaempferitrin. The $\mathrm{MeOH}$ subfractions thus obtained $\left(\mathrm{c}=1 \mathrm{mg} \mathrm{mL}^{-1}\right.$ in $\mathrm{MeOH}$ ) were submitted to HPLC-DAD-MS analysis using the same conditions as described above. 
kaempferol-3,7-O-( $\alpha$ )-dirhamnoside (kaempferitrin)

Amorphous yellowish solid; HPLC-UV $\lambda_{\max } / \mathrm{nm}$ : 230, 264 and 343; HPLC-MS: $m / z$ (rel. int.) $[\mathrm{M}+1]^{+} 579$ (27), 433 (39), 287 (100); ${ }^{1} \mathrm{H}$ NMR (DMSO-d 6 /drops $\mathrm{D}_{2} \mathrm{O}, 400$ MHz): $\delta 6.46$ (d, $J 2.4 \mathrm{~Hz}, \mathrm{H}-6$ ); 6.79 (d, $J 2.0 \mathrm{~Hz}, \mathrm{H}-8$ ); $7.80\left(\mathrm{~d}, J 8.8 \mathrm{~Hz}, \mathrm{H}-2^{\prime}\right.$ ' and 6'); $6.93(\mathrm{~d}, J 8.8 \mathrm{~Hz}, \mathrm{H}-3$ ' and 5'); 5.30 (d, $J 1.6 \mathrm{~Hz}, 3-\mathrm{O}-\mathrm{Rh}-1$ ') ) 3.99 (dd, $J 1.6$ and 3.2 Hz, H-2"); 3.47 (dd $J 3.2$ and 8.8 Hz, H-3"); 3.15 (t, J 8.8 Hz, H-4"); 3.13 (m, H-5"); 0.81 (d, J 5.6 Hz, 3-O-Rh-CH ${ }_{3}$; 5.56 (d, $J 1.6 \mathrm{~Hz}, 7-\mathrm{O}-\mathrm{Rh}-1{ }^{\prime \prime}$ '); 3.84 (dd, $J 1.6$ and $3.4 \mathrm{~Hz}$, H-2"'), 3.64 (dd, $J 3.4$ and 9.2 Hz, H-3"'); 3.31 (t, $J 9.2 \mathrm{~Hz}$, H-4"'); 3.43 (m, H-5"'); 1.13 (d, J 6.4Hz, 7-O-Rh-CH ); ${ }^{13} \mathrm{C}$ NMR (DMSO-d 6 /drops $\mathrm{D}_{2} \mathrm{O}, 100 \mathrm{MHz}$ ): $\delta 157.8(\mathrm{C}-2)$, 134.5 (C-3), 178.0 (C-4), 160.9 (C-5), 99.4 (C-6), 161.7 (C-7), 94.6 (C-8), 156.1 (C-9), 105.8 (C-10), 120.7 (C-1'), 130.7 (C-2' and 6'), 115.4 (C-3' and 5'), 160.1 (C-6'), 101.9 (3-O-Rh-C-1"), 70.0 (C-2"), 70.3 (C-3"), 71.1 (C-4"), 70.7 (C-5"), 17.5 (3-O-Rh-CH $), 98.4$ (7-O-Rh-C-1"”), 69.8 (C-2"'), 70.2 (C-3"'), 71.6 (C-4"”), 70.0 (C-5"'), $17.9\left(7-\mathrm{O}-\mathrm{Rh}_{-} \mathrm{CH}_{3}\right)$.

\section{Results and Discussion}

HPLC-DAD-MS analysis of the isolated solid revealed the presence of a major compound ( $c a .90 \%$ purity) absorbing at UV $\lambda_{\max } / \mathrm{nm}: 230,264$ and 343, with a pseudo- molecular ion $\mathrm{M}+1$ at $\mathrm{m} / \mathrm{z} 579(27 \%)$ and fragment ions of $\mathrm{m} / \mathrm{z}, 433$ (loss of one rhamnose, 146 a.m.u.) and $\mathrm{m} / \mathrm{z} 287$ (aglycone) in the MS (relative abundance proportions: 27:39:100, respectively). ${ }^{1} \mathrm{H}$ and ${ }^{13} \mathrm{C}$ NMR (400 MHz and $100 \mathrm{MHz}$ respectively, DMSO-d/drops $\mathrm{D}_{2} \mathrm{O}$ ) analyses with the help of the correlation on the COSY, HMQC and $\mathrm{HMBC}$ spectra and comparison of their spectral data with those already reported, ${ }^{20,21}$ confirmed the structure of kaempferol-3,7-O- $(\alpha)$-dirhamnoside (kaempferitrin) (Figure 1) for this compound.

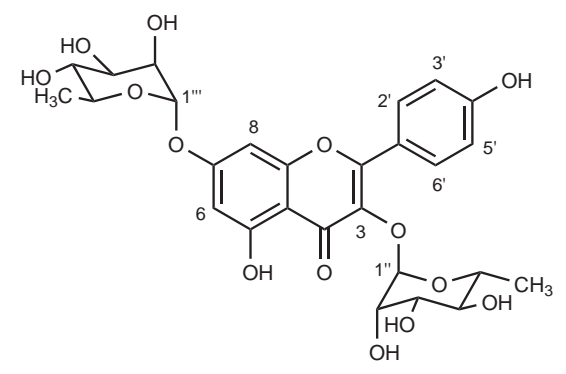

Figure 1. Structure of kaempferitrin.

Screening for kaempferitrin in leaves, stems or bark of $U$. guianensis and $U$. tomentosa through HPLC-DADMS techniques (Figures 2 and 3) and TLC revealed the presence of this compound only in the leaves and stems of $U$. guianensis at a ratio almost thirty six times greater in the

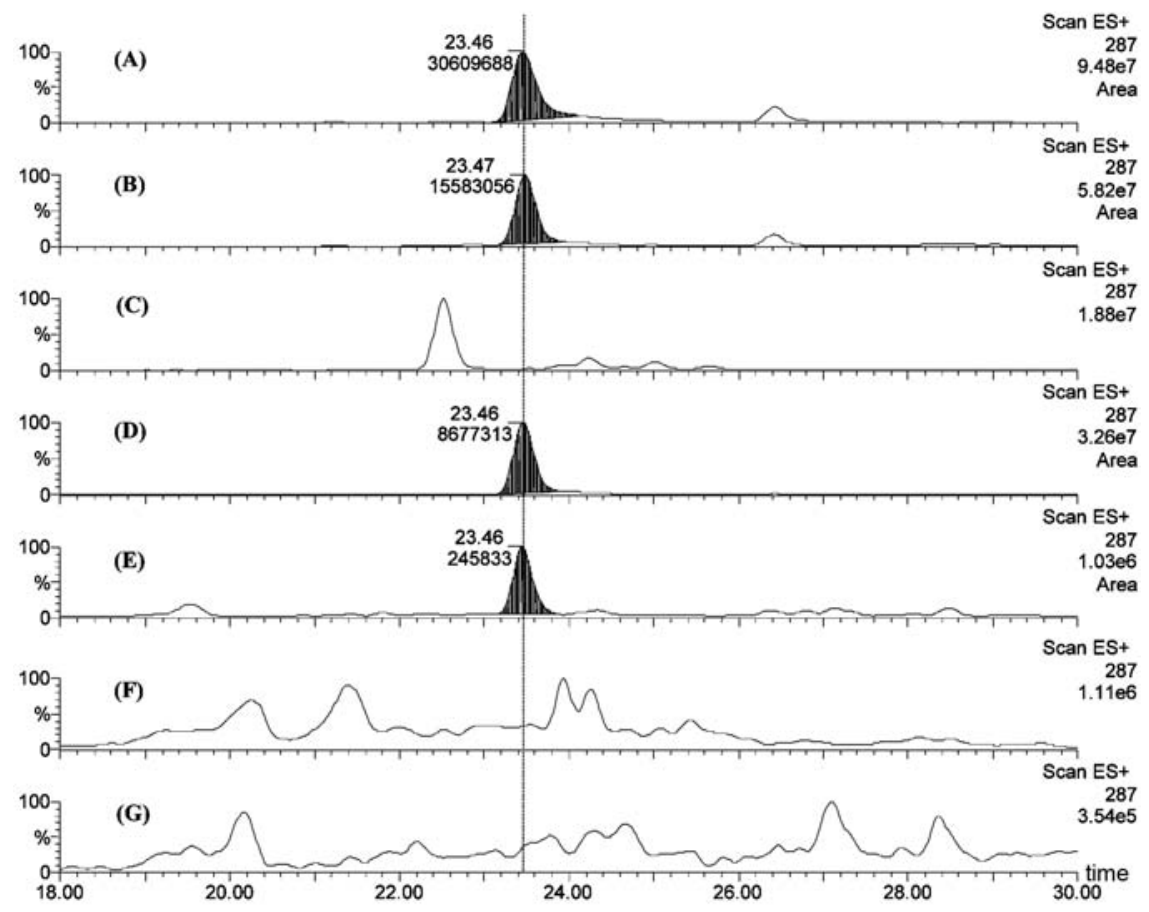

Figure 2. HPLC-MS fragmentograms (extracted ion $\mathrm{m} / \mathrm{z} 287$ ) of isolated kaempferitrin (A) and $\mathrm{MeOH}_{2} \mathrm{H}_{2} \mathrm{O}$ fractions from: leaves of Uncaria guianensis from Mato Grosso (B), bark of Uncaria guianensis from Mato Grosso (C), leaves of Uncaria guianensis from Manaus (D), stems of Uncaria guianensis from Manaus (E), leaves of Uncaria tomentosa (F), bark of Uncaria tomentosa (G). The area and retention time of kaempferitrin are indicated at the top of each peak. 


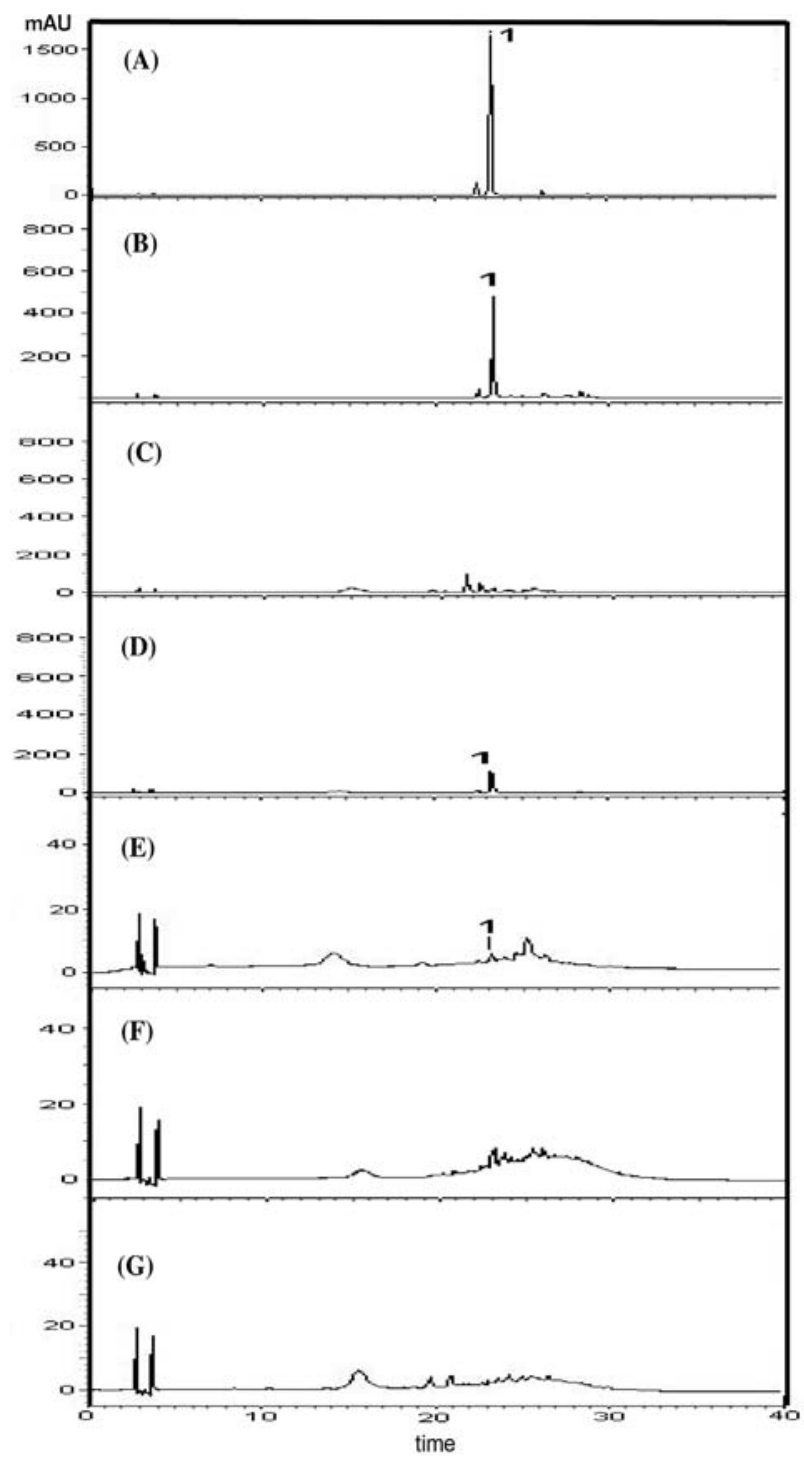

Figure 3. HPLC-UV profiles ( $320 \mathrm{~nm}$ ) of (A) isolated kaempferitrin (1, $\mathrm{t}_{\mathrm{R}}=23.27 \mathrm{~min}$ ) and $\mathrm{MeOH} / \mathrm{H}_{2} \mathrm{O}$ fractions from: (B) leaves of Uncaria guianensis from Mato Grosso (B), bark of Uncaria guianensis from Mato Grosso (C), leaves of Uncaria guianensis from Manaus (D), stems of Uncaria guianensis from Manaus (E), leaves of Uncaria tomentosa (F), bark of Uncaria tomentosa $(\mathrm{G})$.

leaves than in the stems. Kaempferitrin was not found in the bark of the analyzed specimen of $U$. guianensis. Leaves and bark of $U$. tomentosa did not present kaempferitrin.

In addition to reporting for the first time the isolation of kaempferitrin from the Uncaria species and of a flavonoid glycoside from the leaves of Uncaria guianensis, the present study describes the selective production of this compound in leaves and stems of $U$. guianensis; a result that contributes to the chemotaxonomy of the Uncaria species and also could be a useful chemical tool in the differentiation of the leaves of $U$. guianensis from those of $U$. tomentosa. Furthermore, diverse bioactivities are reported for the isolated kaempferitrin; ${ }^{22-24}$ a fact that may be connected to some of the traditional uses and pharmacological properties of $U$. guianensis.

\section{Aknowledgments}

The present work was supported by grants from CNPq, FAPERJ and FIOCRUZ (Brazil). The authors thank to Dr. Peter May and N.G.O. Pro-Natura (Brazil), Dr. João A. Sousa from Embrapa-Acre and Dr. José A. Cabral from CBA-Amazonas for the kind donation of the plant material and Dr. Hélida B. N. Borges from the Central Herbarium of the UFMT, Brazil, for cooperation.

\section{Supplementary Information}

Supplementary data are available free of charge at http://jbcs.sbq.org.br, as PDF file.

\section{References}

1. Ridsdale, C. E.; Blumea 1978, 24, 43.

2. Zevallos-Pollito, P. A.; Tomazello, M.; Acta Amaz. 2006, 36, 169.

3. Jones, K.; Cat's Claw, Healing Vine of Peru, Sylvan Press: Seattle, USA, 1995.

4. Obregón-Vilches, L.; Uña de Gato, Género Uncaria: Estudios Botánicos, Químicos y Farmacológicos de Uncaria tomentosa y Uncaria guianensis, Instituto de Fitoterapia Americano: Lima, Peru, 1997.

5. Heitzmam, M. E.; Neto, C. C.; Winiarz, E.; Vaisberg, A. J.; Hammond, G. B.; Phytochemistry 2005, 66, 5.

6. Phillipson, J. D.; Hemingway, S. R.; Ridsdale, C. E.; Lloydia 1978, 41, 503.

7. Gattuso, M.; Di Sapio, O.; Gattuso, S.; Li Pereyra, E.; Phytomedicine 2004, 11, 213.

8. Laus, G.; Keplinger, D.; J. Chromatogr. 1994, 662, 243.

9. Laus, G.; Keplinger, K.; Phyton 2003, 43, 1.

10. Pereira, R. C. A.; Valente, L. M. M.; Pinto, J. E. B. P.; Bertolucci, S. K. V.; Bezerra, G. M.; Alves, F. F.; Santos, P. F. P.; Benevides, P. J. C.; Siani, A. C.; Rosario, S. L.; Mazzei, J. L.; d'Avila, L. A.; Gomes, L. N. F.; Aquino-Neto, F. R.; Emmerick, I. C. M.; Carvalhaes, S. F.; J. Braz. Chem. Soc. 2008, 19, 1193.

11. Valente, L. M. M.; Rev. Fitos 2006, 2, 48.

12. Sandoval, M.; Okuhama, N. N.; Zhang, X. J.; Condezo, L. A.; Lao, J.; Angeles, F. M.; Musah, R. A.; Bobrowski, P.; Miller, M. J. S.; Phytomedicine 2002, 9, 325.

13. Alvarez, C. M. P.; Sánchez, O.; Stilke, R.; Lock, O.; Rev. Quim., PUCP 1988, 2, 99.

14. Yépez, A. M. P.; Lock, O.; Alvarez, C. M. P.; De Feo, V.; Aquino, R.; De Simone, F.; Pizza, C.; Phytochemistry 1991, 30, 1635 . 
15. Piscoya, J.; Rodriguez, Z.; Bustamante, S. A.; Okuhama, N. N.; Miller, M. J. S.; Sandoval, M.; Inflammation Res. 2001, 50, 442.

16. Lee, K. K.; Zhou, B. N.; Kingston, D. G. I.; Vaisberg, A. J.; Hammond, G. B.; Planta Med. 1999, 65, 759.

17. Carvalho, M. V.; Penido, C.; Siani, A. C.; Valente, L. M. M.; Henriques, M. G. M. O.; Inflammopharmacology 2006, 14, 48.

18. Wagner, H.; Bladt, S.; Plant Drug Analysis: A Thin Layer Chromatography Atlas, Springer: Berlin, Germany, 1996.

19. Miranda, E. M.; Sousa, J. A.; Pereira, R. C. A.; Rev. Bras. Pl. Med. 2003, 5, 41.

20. Pizzolatti, M. G.; Cunha-Jr, A.; Szpoganicz, B.; Sousa, E.; Quim. Nova 2003, 26, 466.
21. Kuçukislamoglu, M.; Yayli, N.; Senturk, H. B.; Genç, H.; Turk. J. Chem. 2000, 24, 191.

22. Gohara, A. A.; Elmazar, M. M. A.; Phytother. Res. 1997, 11, 564.

23. Fang, S. H.; Rao, Y. K.; Tzeng, Y. M.; Bioorg. Med. Chem. 2005, $13,2381$.

24. Sousa, E.; Zanatta, L.; Seifriz, I.; Creezynski-Pasa, T. B.; Pizzolatti, M. G.; Szpoganicz, B.; Silva, F.; J. Nat. Prod. 2004, $67,829$.

Received: January 25, 2009

Web Release Date: June 12, 2009

FAPESP helped in meeting the publication costs of this article. 


\section{Kaempferitrin from Uncaria guianensis (Rubiaceae) and its Potential as a Chemical Marker for the Species}

Ligia M. M. Valente, ${ }^{*, a}$ Carlos H. B. Bizarri, ${ }^{b}$ Sally Liechocki, ${ }^{a}$ Rodolfo S. Barboza, ${ }^{a}$ Djavan da Paixão, ${ }^{a}$ M. Beatriz S. Almeida, ${ }^{b}$ Paulo J. C. Benevides, ${ }^{b}$ Alvicler Magalhães ${ }^{c}$ and Antonio C. Siani ${ }^{b}$

anstituto de Química, Universidade Federal do Rio de Janeiro, 21941-909 Rio de Janeiro-RJ, Brazil ${ }^{b}$ Instituto de Tecnologia em Fármacos, Fundação Oswaldo Cruz, 21041-250 Rio de Janeiro-RJ, Brazil 'Instituto de Química, Universidade Estadual de Campinas, CP 6154, 13083-970 Campinas-SP, Brazil

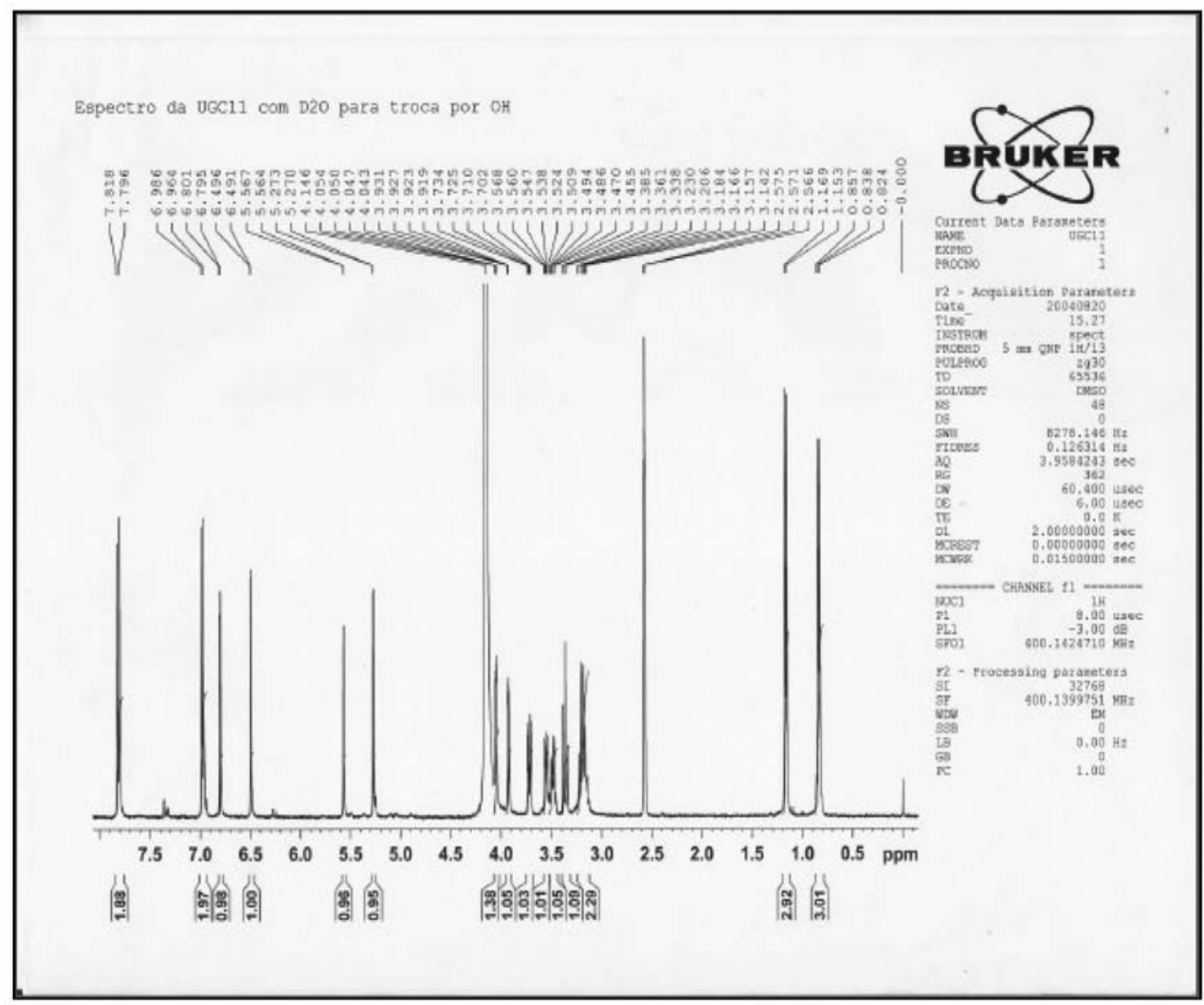

Figure S1. ${ }^{1} \mathrm{H}$ NMR spectrum (400 MHz), in DMSO- $\mathrm{d}_{6} / \mathrm{drops}_{2} \mathrm{O}$ and TMS as internal standard of kaempferitrin. 


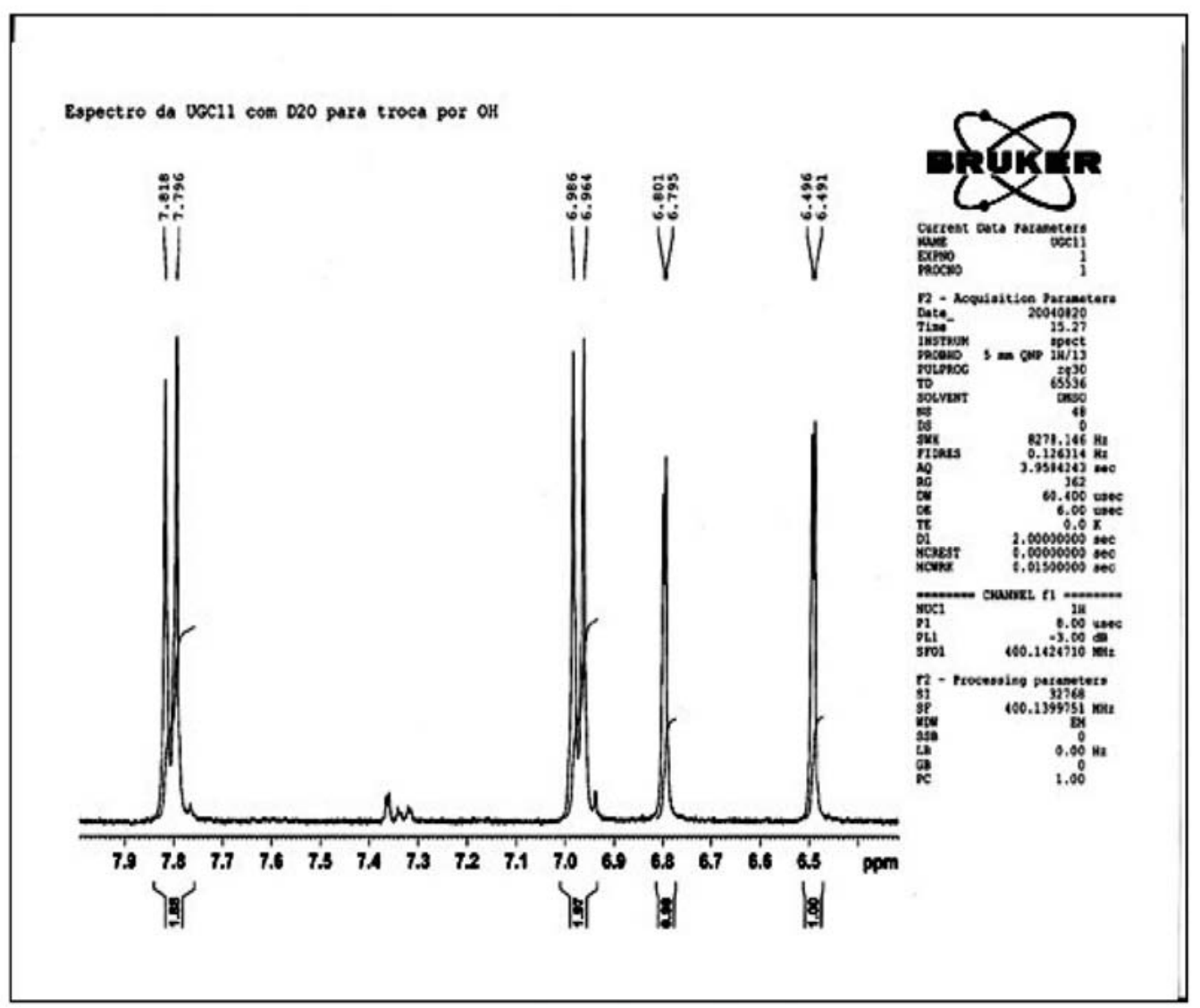

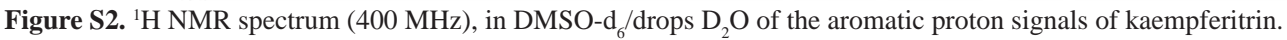

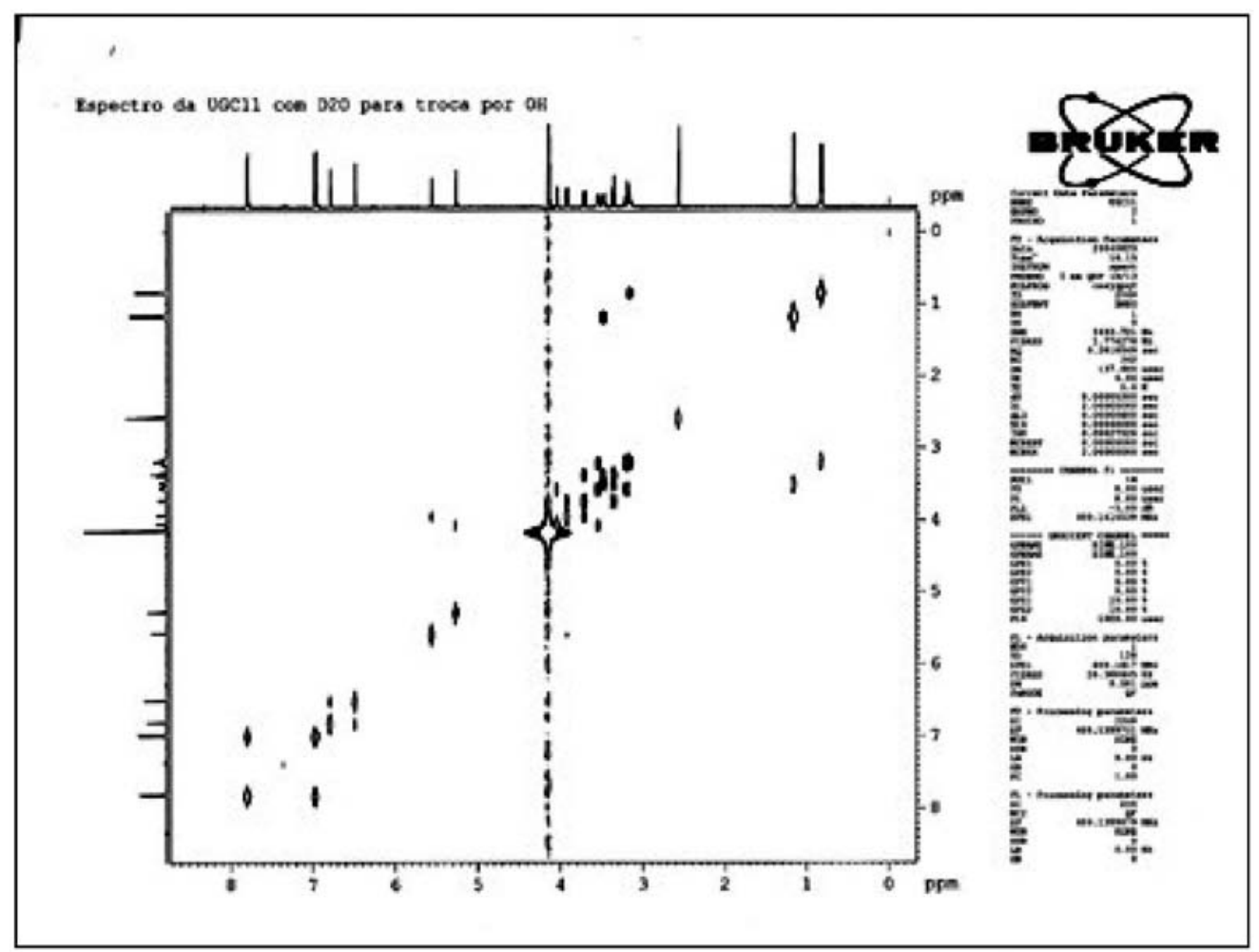

Figure S3. COSY spectrum (400 MHz), in DMSO- $\mathrm{d}_{6} / \mathrm{drops}_{2} \mathrm{O}$ and TMS as internal standard of kaempferitrin. 


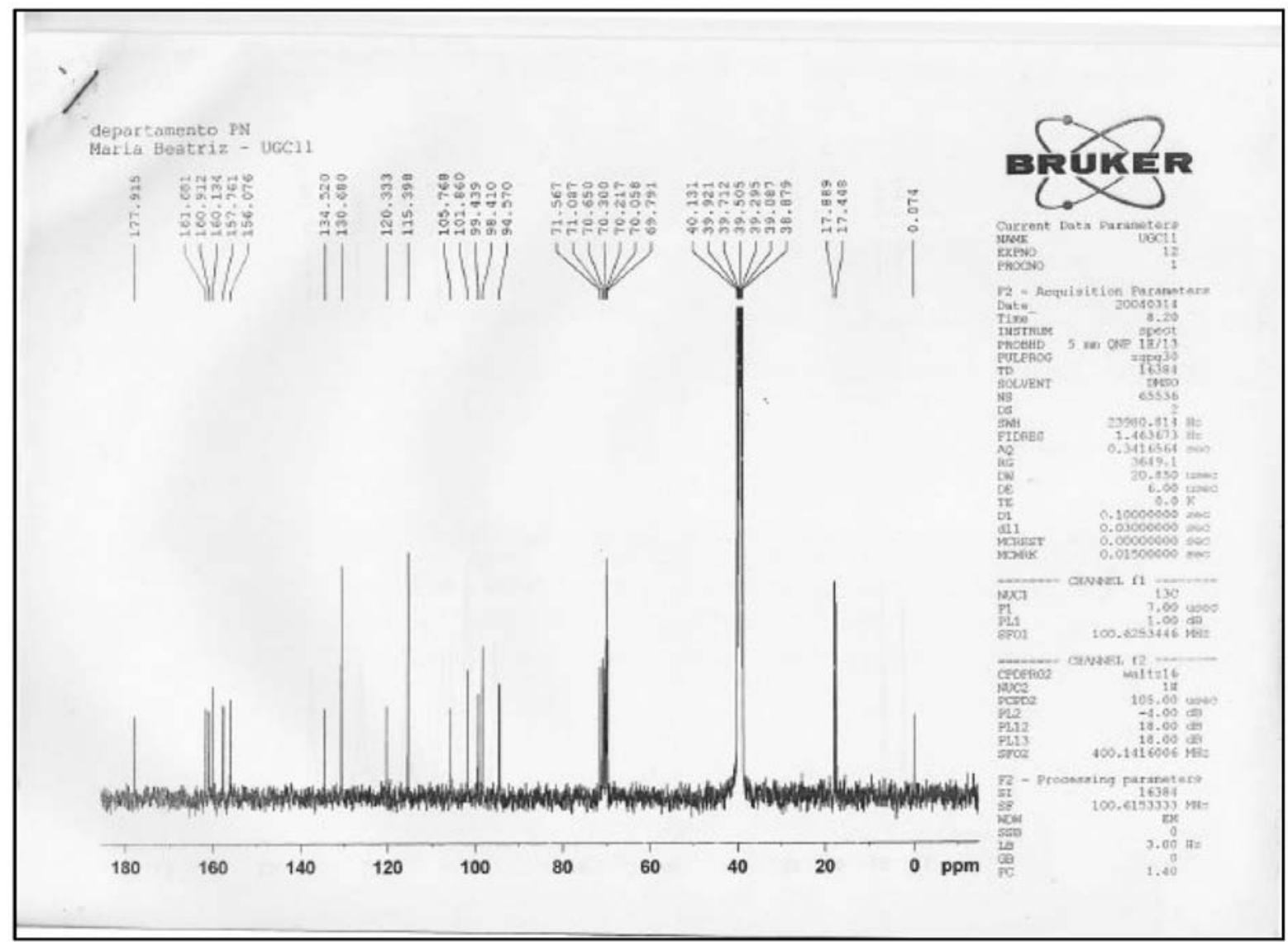

Figure S4. ${ }^{13} \mathrm{C}$ NMR spectrum $(100 \mathrm{MHz})$, in DMSO- $\mathrm{d}_{6} /$ drops $\mathrm{D}_{2} \mathrm{O}$ and TMS as internal standard of kaempferitrin.
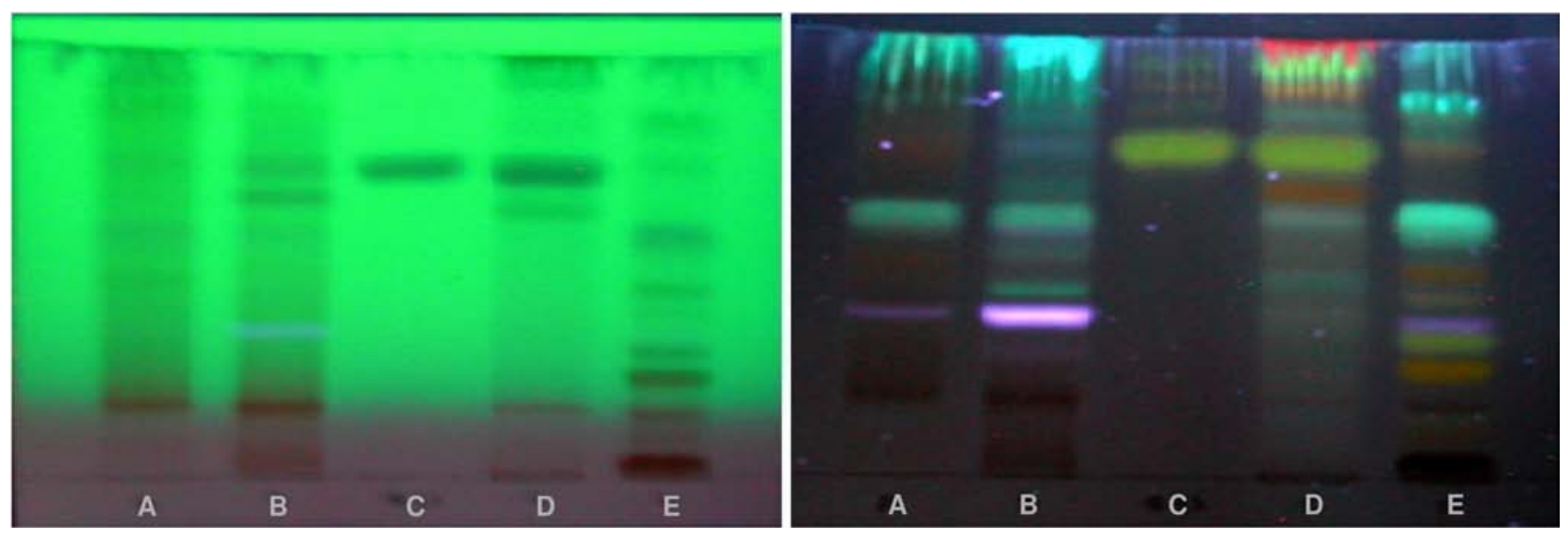

Figure S5. TLC profiles of the $\mathrm{MeOH} / \mathrm{H}_{2} \mathrm{O}$ fractions of: (A) U. tomentosa leaves (25 mg mL $\left.{ }^{-1}\right)$; (B) U. tomentosa barks $\left(25 \mathrm{mg} \mathrm{mL}^{-1}\right)$; (C) kaempferitrin $\left(1 \mathrm{mg} \mathrm{mL}^{-1}\right)$; (D) $U$. guianensis leaves $\left(25 \mathrm{mg} \mathrm{mL}^{-1}\right)$ and (E) U. guianensis barks $\left(25 \mathrm{mg} \mathrm{mL}^{-1}\right)$; silica gel, mobile phase EtOAc/HCOOH/HOAc/H2O 100:11:11:27. The left plate under UV at $254 \mathrm{~nm}$ and the right plate with NP/PEG-UV at $365 \mathrm{~nm}$. Digital photo. 


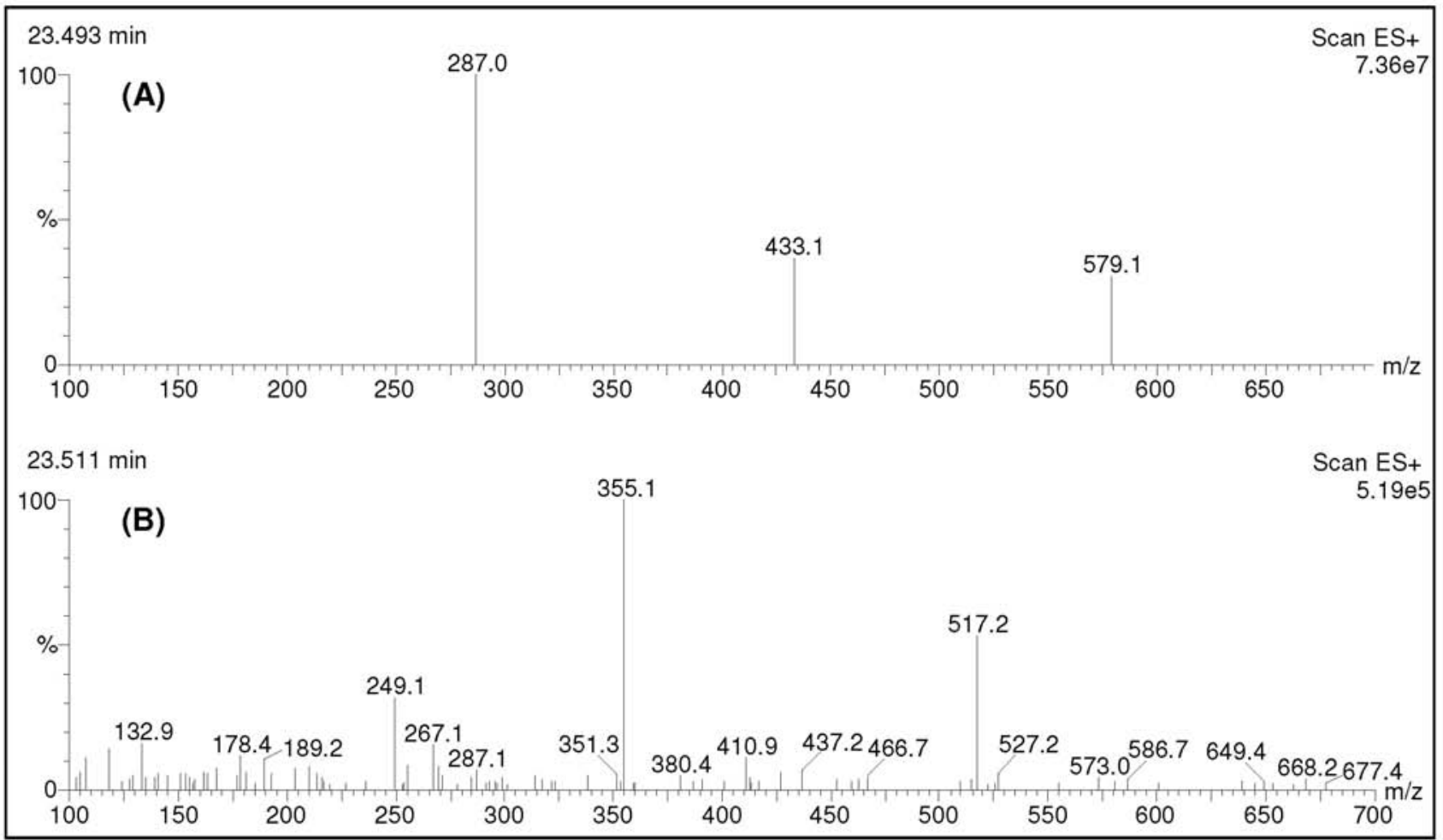

Figure S6. MS of the isolated kaempferitrin at retention time $=23.493 \mathrm{~min}(\mathrm{~A})$ and $\mathrm{MS}$ at the same retention time in leaves of Uncaria tomentosa $\left(\mathrm{R}_{\mathrm{T}}=\right.$ $23.511 \mathrm{~min})(\mathrm{B})$. 